\title{
Sağhıkı Beslenme ve Obezite Danışmanlığı Birimine Başvuran Yetişkin Bireylerde Ailesel Obezite Varlığının Bireydeki Obezite Durumuna Etkilerinin İncelenmesi
}

Investigation of the Effects of Familial Obesity on the Individual's Obesity Status in Adults Applied to the Healthy Nutrition and Obesity Counseling Unit

Ayla AÇIKGÖZ ${ }^{1}$, Selin KARAER TAŞTAN ${ }^{2}$, Ayşe Gülay ŞAHAN ${ }^{3}$

\section{ÖZ}

$\mathrm{Bu}$ araştırmanın amacı; birinci basamak sağlık hizmetinde Sağlıklı Beslenme ve Obezite Danışmanlığı Birimine başvuran 20 yaş ve üstü erişkin bireylerde obezite sıklığının belirlenmesi, ailesel obezite varlığının bireydeki obezite durumuna etkilerinin araştırılmasıdır. Tanımlayıcı, kesitsel tipte yapılan bu araştırmanın katılımcıları 01.01.2016 ile 30.12.2017 tarihleri arasında Sağlıklı Beslenme ve Obezite Danışmanlığı Birimi'ne ilk kez başvuran $\geq 20$ yaş 657 bireyden oluşmaktadır. Birime başvuran bireylerin özellikleri ve diyetisyenlerin sunduğu hizmetlerin kaydedildiği veri tabanından veriler retrospektif olarak birimde çalışan diyetisyen tarafından elde edilmiştir. Bireylerin beden kütle indeksini hesaplamada diyetisyen tarafindan ölçülen boy uzunluğu ve vücut ağırlığı değerleri kullanılmıştır. Araştırma grubunun \%58,4'ünün obez, $\% 31,7$ 'sinin fazla kilolu olduğu saptanmıştır Katılımciların \%65,1'inin ailesinde en az bir bireyin obez olduğu belirlenmiştir. Araştırmaya katılan erkek bireylerde, evli olan bireylerde, kronik hastalık tanısı olan bireylerde obezite sıklığının daha yüksek olduğu $(\mathrm{p}<0,05)$; obezitenin yaş ile arttı̆̆ artışı ile azaldığı saptanmıştır $(p<0,01)$. Ailesinde obezite öyküsü olmayanlara göre ailesinde obezite öyküsü olan bireylerde obezite riskinin 1,74 kat daha yüksek olduğu saptanmıştır. Bu araştırmadan elde edilen sonuçlar aile öyküsünde obezite tanısı olan bireylere yönelik sağlıklı beslenme ve yaşam tarzı alışkanlıkları konusunda birinci basamak sağlık hizmetleri çalışanlarına yol gösterici olabilir. Aile öyküsünde obezite tanısı olan bireylere, obez olmasa dahi hatalı beslenme alışkanlıkları ve sağlıklı beslenme konularında davranış değişimine yönelik danışmanlık yapılması önemlidir. $\mathrm{Bu}$ bireylerin izleminde aile yakınları ile birlikte değerlendirilmesi bireylere yapılacak öneriler arasında yer alabilir.

Anahtar Kelimeler: Beden kütle indeksi, Beslenme, Obezite.

\begin{abstract}
The aim of this study is to determine the prevalence of obesity in adults aged 20 and over who applied to the Healthy Nutrition and Obesity Counseling Unit in primary health care, and to investigate the effects of familial obesity on the obesity status of the individual. Participants of this descriptive, cross-sectional study consist of 657 people aged $\geq 20$ who applied to the Healthy Nutrition and Obesity Counseling Unit for the first time between 01.01.2016 and 30.12.2017. The data were collected by the dietician working in the unit. Data were obtained retrospectively from the database in which the characteristics of the individuals who applied to the unit and the services provided by dietitians working in the unit were recorded. Height and weight values measured by the dietician were used to calculate the body mass index of the individuals. $58.4 \%$ of the participants were obese and $31.7 \%$ were overweight. At least one member of the family of $65.1 \%$ of the participants was determined to be obese. The prevalence of obesity is higher in males participating in the study, in those who are married, and those with chronic diseases $(\mathrm{p}<0.05)$. It was determined that obesity increased with age and decreased with an increase in education level $(p<0.01)$. The obesity risk was found to be 1.74 times higher in those with a family history of obesity compared to those without a family history of obesity. The results obtained from this study may guide primary health care workers about healthy nutrition and lifestyle habits for individuals with a family history of obesity. It is important to provide counseling to individuals with a family history of obesity, even if they are not obese, for behavioral change in nutritional type and healthy eating. Evaluation of these individuals together with their family relatives in the follow-up may be among the recommendations to be made to the individuals.
\end{abstract}

Keywords: Body mass index, Nutrition, Obesity

Dokuz Eylül Üniversitesi Girişimsel Olmayan Araştırmalar Etik Kurulu’ndan izin alınmıştır (19.07.2018, Karar no: 2018/18-36).

${ }^{1}$ Doç. Dr., Ayla AÇIKGÖZ, Halk Sağlığı, Dokuz Eylül Üniversitesi Sağlık Hizmetleri Meslek Yüksekokulu, ayla.acikgoz@deu.edu.tr, ORCID: 0000-0001-7749-705X

${ }^{2}$ Diyetisyen, Selin KARAER TAŞTAN, Kütahya Sağlık Bilimleri Üniversitesi Evliya Çelebi Eğitim ve Araştırma Hastanesi, selinkaraer12@gmail.com, ORCID: 0000-0002-9468-5965

${ }^{3}$ Doktora öğrencisi, Ayşe Gülay ŞAHAN, Geriatri, Ege Üniversitesi Geriatri Anabilim Dalı, gulaysahan2011@hotmail.com, ORCID: 00000002-6665-4563 


\section{Gİiș}

Obezite, günümüzde tüm dünyayı etkileyen en önemli halk sağlığı sorunlarından biridir ve bireylerin yaşam süresini ve kalitesini azaltan kronik bir hastal1ktır. $^{1-3}$

Obezite yaygınlığının dünya genelinde son 40 y1l içerisinde yaklaşık olarak üç kat arttığı belirtilmektedir. Dünya Sağlık Örgütü (DSÖ) tarafından, tüm dünyada $\geq 18$ yaş grubu toplumun \%39'unun fazla kilolu, \%13'ünün ise obez olduğu bildirilmiștir. ${ }^{2}$ Türkiye genelinde 19 yaş ve üzeri bireylerde fazla kilolu olma ve obezite siklığı erkeklerde sirasiyla \%39,1 ve \%20,5'tir. Kadınlarda ise bu oranlar ters olup obezite oranı daha fazladır, bu değerler sirasıyla $\% 29,7$ ve $\% 41,0$ 'dır. Türkiye'de tüm yetişkin bireylerde fazla kilolu olma sıklı̆̆ $1 \% 34,6$, obezite görülme sıklığı \%30,3'tür. ${ }^{4}$ Türkiye Beslenme ve Sağlık Araştırması'nda (TBSA 2017) 19 yaş ve üzeri toplumda fazla kilolu sıklığı \%36,9, obezite sıklığı \%32,2 olarak bulunmuştur. $^{5}$

Obezite; aralarında kardiyovasküler hastalıklar, diyabetes mellitus, bazı kanser türleri, solunum sistemi hastalıkları ve kasiskelet sistemi hastalıklarının bulunduğu çok sayıda hastalık için risk faktörüdür. ${ }^{1,3,6}$ Fazla kilolu olma durumu ve obezite nedeniyle her yıl en az 2,8 milyon birey yaşamını kaybetmektedir. Bu nedenle DSÖ, bulaşıcı olmayan hastalıkların önlenmesi kapsamında obezitenin önlenmesini temel hedefleri arasına almıştır. ${ }^{6}$ Tüm dünyada obeziteyi önleyebilmek için DSÖ ve çok sayıda uluslararası kuruluş çeşitli programlar geliştirmiştir. $\mathrm{Bu}$ programlarda beslenme alışkanlıklarının düzeltilmesi ve fiziksel aktivitenin önem kazandığ 1 bir yaşam tarzının yerleşmesi konularında çalışmalar yapılmaktadır., ${ }^{4,6}$ Türkiye'de obezite sorunu Sağlık Bakanlığı'nın ulusal halk sağlığı politikaları ve programlarında ülke çapında mücadele edilmesi gereken temel hedeflerinden biridir. Türkiye Sağlıklı Beslenme ve Hareketli Hayat Programı doğrultusunda ülke çapında birinci basamak sağl1k kurumlarında sağlıklı beslenmenin desteklenmesi ve obezite ile mücadele konularında hizmet sunmak üzere personel (diyetisyen, hekim, hemşire, sağlık memuru, psikolog, fizyoterapist, gida mühendisi) görevlendirilmiştir. ${ }^{4}$ Birinci basamak sağlik hizmetlerinde obezitenin önlenmesi ve sağlıklı yaşamın sürdürülmesinde diyetisyenin rolü oldukça önemlidir. ${ }^{7}$

Obezitenin etyopatogenezi kesin bir şekilde tanımlanmamış olsa da günlük gereksinimden fazla enerji alımı ve sedanter yaşam tarzının obezite gelişimindeki en önemli etmenler olduğu düşünülmektedir. $\mathrm{Bu}$ etmenler dışında; yaş, cinsiyet, öğrenim düzeyi, gelir durumu, sosyokültürel etmenler, genetik, metabolik bozukluklar, endokrin sorunlar ve psikolojik sorunların obezite gelişimi üzerinde doğrudan ya da dolaylı olarak etkilerinin olduğu belirtilmektedir. ${ }^{3,6,8}$ Araştırmalarda obezitenin etyolojisinde genetik yatkınlığın önemli rol oynadığ saptanmıştır. ${ }^{9-12}$ Benzer şekilde çevresel koşullar ve yaşam tarzı obezitenin gelişimini etkileyen etmenler arasındadir. ${ }^{13}$ Çalışmalarda ailede edinilen yanlış ve aşırı yeme alışkanlığının obezite gelişiminde önemli olabileceği belirtilmektedir. Ailesinde obezite öyküsü olan bireylerde fazla kilolu olma ve obezite sıklığının arttığını gösteren çalışmalar bulunmaktadır. ${ }^{9-15}$ Ailesinde obezite öyküsü olan bir bireyin olmayanlara göre obezite riski 2-3 kat daha fazladır. Özellikle annede obezite varlığının çocuktaki obezite riski üzerine etkisi daha fazla olmakla birlikte, her iki ebeveynin obez olması bireyin obez olma riskini daha da artırmaktadır. $^{2,10,12,16}$ Fiziksel aktivite eksikliği ve sedanter yaşam tarzı gibi bireyleri hareketsizliğe iten alışkanlıklar ve dengesiz beslenme çoğunlukla aile yaşamı ve yaşanılan ortam ile ilişkilidir. ${ }^{10,12}$

Obez bireye tedavi yaklaşımında genetik yatkınlığın, anne babanın yaşam tarzından kaynaklanan yanlış beslenme ve fiziksel inaktivite gibi alışkanlıkların etkisinin belirlenebilmesi için ailesel obezitenin belirlenmesi önerilmektedir. ${ }^{3,10,17}$ Ülkemizde birinci basamak sağlik hizmetinde obezite danışmanlığ 1 verilen birimlerin verilerinin değerlendirildiği çalışmalar oldukça az 
sayıdadır. ${ }^{15,18} \mathrm{Bu}$ veriler obeziteyle ilişkili faktörlerin belirlenmesi bakımından önemlidir.

$\mathrm{Bu}$ araştırmanın amacı; birinci basamak sağlık hizmeti sunan bir Sağlıklı Beslenme ve Obezite Danışmanlığg Birimine (SBODB) başvuran 20 yaş ve üstü erişkinlerde obezite sıklığının belirlenmesi, ailesel obezite varlığının bireysel obezite durumu üzerine etkilerinin araştırılmasıdır.

\section{MATERYAL VE METOT}

Tanımlayıcı, kesitsel tipte yapılan bu araştırma Sağlık Bakanlığına bağlı olarak birinci basamak sağlık hizmeti sunan bir SBODB'de gerçekleştirilmiştir. Araştırmanın örneklemini 01.01.2016 ile 30.12.2017 tarihleri arasında SBODB'ye ilk kez başvuran $\geq 20$ yaş bireyler oluşturmaktadır $(n=657)$. Araştırmanın verileri SBODB'de çalışan araştırma ekibindeki diyetisyen tarafından toplanmıștır. Veriler, SBODB'ye başvuran bireylerin özellikleri ve diyetisyenlerin sunduğu hizmetlerin kaydedildiği bilgisayar temelli olan bir veri tabanından retrospektif olarak elde edilmiştir. Veri tabanından araştırma kapsamında incelenen bilgiler birey bazında elde edilerek, bu araştırma için oluşturulan veri tabanına (SPSS 22.0) aktarılmıştır. Araştırmada incelenen tüm değişkenlerin verileri tam olarak doldurulan bireyler araștırmaya dahil edilmiş, eksik verisi olanlar dışlanmıștır. Bu araştırmada herhangi bir anket ya da veri kayıt formu kullanılmamıştır.

Sosyodemografik özellikler (yaş, cinsiyet, öğrenim durumu, medeni durum), kronik hastalık varlığı, fiziksel aktivite/egzersiz yapma durumu, ailede obezite varlığı, obez olan bireylerin yakınlığı (anne, baba, kardeş, çocuk) bireylerin beyanına dayalı olarak elde edilmiş, boy uzunluğu $(\mathrm{cm})$ ve vücut ağırlığ (kg) ölçümleri diyetisyen tarafından ölçülerek belirlenmiştir. Vücut ağırlığı ölçümü Tanita BC 330, boy ölçümü Seca stadiometer ile yapılmıştır.

$\mathrm{Bu}$ çalıșmada, her katılımcı için beden kütle indeksi (BKI) hesaplanmıştır. Beden kütle indeksini hesaplamak için ağırlık $(\mathrm{kg})$, boyun $(\mathrm{m})$ karesine $\left(\mathrm{kg} / \mathrm{m}^{2}\right)$ bölünmüștür. ${ }^{19}$ Beden kütle indeksi, DSÖ'ye göre sınıflandırılmıştır $\quad\left(<18,50 \quad \mathrm{~kg} / \mathrm{m}^{2}\right.$ : zayıf; $18,50-24,99 \mathrm{~kg} / \mathrm{m}^{2}$ : normal; 25,00-29,99 $\mathrm{kg} / \mathrm{m}^{2}$ : fazla kilolu; $\geq 30,00 \mathrm{~kg} / \mathrm{m}^{2}$ : obez;
30,00-34,99 kg/m²: I. derece obez; 35,00$39,99 \mathrm{~kg} / \mathrm{m}^{2}$ : II. derece obez; $\geq 40,00 \mathrm{~kg} / \mathrm{m}^{2}$ : III. derece obez). ${ }^{19}$ Araştırmanın bağımlı değişkeni bireyin BKİ düzeyidir. Analizlerde bireyler BKI düzeyine göre zayıf/normal, fazla kilolu ve obez olarak gruplanmıştır. Araştırmanın bağımsız değişkenleri yaş, cinsiyet, öğrenim durumu, medeni durum, kronik hastalık varlığ $\breve{1}_{\text {(kalp-damar }}$ hastalıkları, hipertansiyon, diyabetes mellitus, solunum sistemi hastalıkları, astım, alerji, kanser, psikiyatrik hastalıklar, tiroid fonksiyon bozuklukları), fiziksel aktivite/egzersiz yapma durumu, ailede obezite varlığı, obez olan kişilerin yakınlık düzeyidir.

\section{Araştırmanın Etik Yönü}

Araştırmaya başlamadan önce Dokuz Eylül Üniversitesi Girişimsel Olmayan Araştırmalar Etik Kurulu'ndan izin alınmıştır (19.07.2018, Karar no: 2018/18-36).

\section{İstatistiksel Analiz}

Veriler SPSS for Windows 22.0 (IBM Corp., Armonk, NY, USA) istatistik paket programı kullanılarak çözümlenmiştir. Araştırmada sınıflanmış değişkenler sayı, yüzde dağılımları ve olasılıklar oranı (OR), $\% 95$ güven aralıklarıyla (GA) sunulmuştur. Kolmogorov-Smirnov testi sonuçlarına göre verilerin normal dağıldiğ İstatistiksel çözümlemede bağımsız değişkenlerle bağımlı değişken arasındaki ilișkiyi belirlemede Pearson ki-kare, eğimde ki-kare testi ve bağımsız gruplarda $\mathrm{t}$ testi kullanılmıştır.

Obeziteyi etkileyen faktörlerin birlikte etkisini değerlendirmek için yapılan lojistik regresyon analizinde ailesel obezite öyküsü, yaş, cinsiyet, öğrenim durumu, kronik hastalık varlığ 1 ve fiziksel aktivite/egzersiz yapma durumuna göre düzeltme yapılmıştır. 
İstatistik anlamlılık düzeyi $\mathrm{p}<0,05$ kabul edilmiştir.

\section{Araştırmanın Kısıtlılıkları}

$\mathrm{Bu}$ çalışmanın kısıtlılıkları birinci basamakta SBODB'ye başvuranlarda yapılması nedeniyle genel toplum hakkında net bir bilgi verememesi, aile öyküsünün kayıtlara

dayanmayıp Original Article

\section{BULGULAR VE TARTIŞMA}

Araştırmaya katılan bireylerin soosyodemografik özellikleri Tablo 1'de gösterilmiştir. Katılımcıların \%17,7'si erkek, \%82,3'ü kadın, \%80,5'i evli olup, çoğunluğun $(\% 60,9)$ herhangi bir kronik hastalığ1 yoktur. Araştırma grubunun \%58,4'ü obez, \%31,7'si fazla kilolu, \%9,6's1 normal ve $\% 0,5$ 'i zayiftır (Tablo 1 ).

Tablo 1. Katılımcıların Sosyodemografik ve BKI Özellikleri $(n=657)$

\begin{tabular}{|c|c|c|c|}
\hline Değişkenler & & Sayı & $\%$ \\
\hline \multirow[t]{2}{*}{ Cinsiyet } & Erkek & 116 & 17,7 \\
\hline & Kadın & 541 & 82,3 \\
\hline \multirow[t]{5}{*}{ Yaş grubu } & $20-29$ & 104 & 15,8 \\
\hline & $30-39$ & 207 & 31,5 \\
\hline & $40-49$ & 185 & 28,2 \\
\hline & $50-59$ & 118 & 18,0 \\
\hline & $\geq 60$ & 43 & 6,5 \\
\hline \multirow[t]{3}{*}{ Medeni durum } & Evli & 529 & 80,5 \\
\hline & Bekar & 106 & 16,1 \\
\hline & $\begin{array}{l}\text { Boşanmış/eşi } \\
\text { ölmüş }\end{array}$ & 22 & 3,3 \\
\hline \multirow{4}{*}{$\begin{array}{l}\text { Öğrenim } \\
\text { durumu }\end{array}$} & Ortaokul ve alt1 & 232 & 35,3 \\
\hline & Lise & 142 & 21,6 \\
\hline & Üniversite & 232 & 35,3 \\
\hline & Lisansüstü & 12 & 1,8 \\
\hline \multirow[t]{2}{*}{ Kronik hastalık } & Var & 257 & 39,1 \\
\hline & Yok & 400 & 60,9 \\
\hline \multirow{2}{*}{$\begin{array}{l}\text { Fiziksel } \\
\text { aktivite/Egzersiz }\end{array}$} & Yapan & 322 & 49,0 \\
\hline & Yapmayan & 335 & 51,0 \\
\hline \multirow[t]{6}{*}{ BKİ düzeyi } & Zayif & 3 & 0,5 \\
\hline & Normal & 63 & 9,6 \\
\hline & Fazla kilolu & 208 & 31,7 \\
\hline & 1.Derece obez & 204 & 31,1 \\
\hline & 2.Derece obez & 118 & 18,0 \\
\hline & 3.Derece obez & 61 & 9,3 \\
\hline
\end{tabular}

Katılımciların \%65,1'inin ailesinde en az bir bireyin obez olduğu belirlenmiştir. Ailesindeki obez bireyin yakınlığ incelendiğinde en fazla obezite öyküsünün annede olduğu görülmüştür (Tablo 2).

Tablo 2. Katılımcıların Ailesel Obezite Öyküsü Özellikleri

\begin{tabular}{llll}
\hline Özellikler & & Sayı & \% \\
& & & \\
\hline $\begin{array}{l}\text { Ailede } \\
\text { obezite }\end{array}$ & Var & 428 & 65,1 \\
& & & \\
& Yok & 229 & 34,9 \\
& & & \\
\hline & Hepsi & 26 & 6,1 \\
& Anne & 107 & 16,3 \\
& Baba & 32 & 4,9 \\
& Kardeş & 50 & 7,6 \\
Obez & Çocuk & 29 & 4,4 \\
bireyin & Anne+baba & 41 & 6,2 \\
yakınlık & Anne+baba+kardeş & 46 & 7,0 \\
durumu & Anne+kardeş & 53 & 8,1 \\
& Anne+baba+çocuk & 6 & 0,9 \\
& Anne+çocuk & 15 & 2,3 \\
& Baba+çocuk & 2 & 0,3 \\
& Baba+kardeş & 9 & 1,6 \\
& Kardeş+çocuk & 12 & 1,8 \\
\hline
\end{tabular}

Ailesel obezite ile katılımc1 bireylerin BKİ düzeyleri arasındaki ilişki Tablo 3 'te gösterilmiştir. Ailesinde obezite öyküsü olanlarda obezitenin daha s1k görüldüğü belirlenmiştir $(p<0,01)$. Hem annenin hem de babanın obez olmasi bireylerin obez olmasını anlamlı olarak artırmaktadır $(\mathrm{p}<0,01)$ (Tablo 3).

Yapılan ki-kare analizi sonuçlarına göre erkeklerde obezite sıklığı kadınlara göre daha yüksektir $(p<0,05)$. Bununla birlikte erkekler ve kadınların BKİ ortalamaları (sırasıyla $32,10 \pm 5,65,31,80 \pm 6,16$ ) arasinda anlaml fark saptanmamıştır ( $>>0,05)$. Evli olanlarda, herhangi bir kronik hastalığı olanlarda 
obezitenin anlamlı olarak fazla görüldüğü saptanmıştır $(p<0,01)$. Öğrenim düzeyi azaldıkça obezitenin anlamlı olarak arttığ1 belirlenmiştir $(p<0,01)$. Katılımcıların yaşı arttıkça obezite sıklığının da anlamlı olarak $\operatorname{arttığı~bulunmuştur~}(\mathrm{p}<0,01)$ (Tablo 4$)$.

Tablo 3. Ailesel Obezite İle SBODB'ye Başvuran Bireylerin BKİ Düzeyleri Arasındaki İlişsi

\begin{tabular}{lllll}
\hline Aile öyküsü & \multicolumn{4}{c}{ BKİ } \\
\cline { 2 - 5 } & $\begin{array}{l}\text { Zayıf/Nor } \\
\text { mal } \\
\text { Sayı (\%) }\end{array}$ & $\begin{array}{l}\text { Fazla } \\
\text { kilolu } \\
\text { Sayı (\%) }\end{array}$ & $\begin{array}{l}\text { Obez } \\
\text { sayı (\%) }\end{array}$ & p** \\
\hline Ailede obezite (n=657) & & & \\
Var & $31(7,2)$ & $128(29,9)$ & $269(62,9)$ & $\mathbf{0 , 0 0 1}$ \\
Yok & $35(15,3)$ & $80(34,9)$ & $114(49,8)$ & \\
\hline Ebeveynde obezite varlı̆ı̆ (n=337) & & \\
Her ikisinde & $9(7,6)$ & $28(23,5)$ & $82(68,9)$ & $\mathbf{0 , 0 3 7 *}$ \\
Sadece anne & $18(8,3)$ & $74(33,9)$ & $126(57,8)$ & \\
ya da sadece & & & & \\
baba & & & & \\
\hline Ailede obez kişi sayısı (428) & & & \\
1 kişi & $16(7,3)$ & $70(32,1)$ & $132(60,6)$ & 0,577 \\
$\geq 2$ kişi & $15(7,1)$ & $58(27,6)$ & $137(65,2)$ & \\
\hline
\end{tabular}

*Eğimde kikare ** Pearson kikare

Tek değişkenli olasılıklar oranı hesaplamasında 20-29 yaş grubuna göre 5059 yaş grubunda obezite 3,34 kat (Kaba $\mathrm{OR}=3,34$, \%95 GA: 1,92-5,86), $\geq 65$ yaş grubunda 6,37 kat (Kaba OR=6,37, \%95 GA: 2,75-16,10) artmış bulunmuştur. Erkeklerde obezite 1,66 kat (Kaba OR=1,66, \%95 GA: 1,09-2,56) fazla bulunmuştur. Üniversite ve üstü eğitimi olanlara göre lise düzeyinde eğitimi olanlarda obezite 2,56 kat (Kaba $\mathrm{OR}=2,56$, \%95GA: 1,69-3,91), ortaokul ve altında eğitimi olanlarda ise 4,08 kat (Kaba $\mathrm{OR}=4,08$, \%95 GA: 2,80-5,99) artmıştır. Kronik hastalığı olanlarda obezite 2,43 kat (Kaba OR=2,43 \%95 GA: 1,74-3,40) daha fazla bulunmuştur. Ailesinde obezite öyküsü olanlarda obezite 1,70 kat (Kaba OR01,70 \%95GA: 1,23-2,36) daha yüksek bulunmuştur (Tablo 5).
Tablo 4. Katılımcıların Sosyodemografik Ve Diğer Bazı Özellikleri İle BKİ Düzeyleri Arasındaki İliş̧i ( $N=657$ )

\begin{tabular}{|c|c|c|c|c|c|}
\hline \multirow{3}{*}{$\begin{array}{l}\text { Sosyodemograf } \\
\text { ik özellikler }\end{array}$} & \multicolumn{4}{|c|}{ BKI } & \multirow{3}{*}{$\mathbf{p}$} \\
\hline & \multicolumn{2}{|c|}{ Obez } & \multicolumn{2}{|c|}{$\begin{array}{l}\text { Obez } \\
\text { olmayan\# }\end{array}$} & \\
\hline & Sayı & $\%$ & Sayı & $\%$ & \\
\hline \multicolumn{6}{|l|}{ Cinsiyet } \\
\hline Erkek & 79 & 68,1 & 37 & 31,9 & \multirow{2}{*}{$\mathbf{0 , 0 1 8 * *}$} \\
\hline Kadın & 304 & 56,2 & 237 & 43,8 & \\
\hline \multicolumn{6}{|l|}{ Yaş grubu } \\
\hline $20-29$ & 42 & 40,4 & 62 & 59,6 & \multirow{5}{*}{$0,001 *$} \\
\hline $30-39$ & 113 & 54,6 & 94 & 45,4 & \\
\hline $40-49$ & 111 & 60,0 & 74 & 40,0 & \\
\hline $50-59$ & 82 & 69,5 & 36 & 30,5 & \\
\hline 60 üstü & 35 & 81,4 & 8 & 18,6 & \\
\hline \multicolumn{6}{|l|}{ Medeni durum } \\
\hline Evli & 325 & 61,4 & 204 & 38,6 & \multirow{3}{*}{$\mathbf{0 , 0 0 1} * *$} \\
\hline Bekar & 45 & 42,5 & 61 & 57,5 & \\
\hline $\begin{array}{l}\text { Boşanmış/eşi } \\
\text { ölmüş }\end{array}$ & 13 & 59,1 & 9 & 40,9 & \\
\hline \multicolumn{6}{|l|}{ Öğrenim durumu } \\
\hline Ortaokul ve altı & 173 & 74,6 & 59 & 25,4 & \multirow{3}{*}{$0,001 *$} \\
\hline Lise & 92 & 64,8 & 50 & 35,2 & \\
\hline $\begin{array}{l}\text { Üniversite ve } \\
\text { üstü }\end{array}$ & 118 & 41,7 & 165 & 58,3 & \\
\hline \multicolumn{6}{|l|}{ Kronik hastalık } \\
\hline Var & 182 & 70,8 & 74 & 29,2 & \multirow{2}{*}{$0,001 * *$} \\
\hline Yok & 201 & 50,2 & 199 & 49,8 & \\
\hline \multicolumn{6}{|c|}{ Fiziksel aktivite/Egzersiz } \\
\hline Yapan & 179 & 55,6 & 143 & 44,4 & \multirow{2}{*}{$0,168 * *$} \\
\hline Yapmayan & 204 & 60,9 & 131 & 39,1 & \\
\hline
\end{tabular}

Tek değişkenli analizde yaş artışının obezite riskini anlamlı olarak artırdığ belirlenmişken yapılan lojistik regresyon analizinde bu anlamlılık ortadan kalkmıştır, ancak ailesel obezitenin, cinsiyetin, öğrenim durumu ve kronik hastalık varlığının bireysel obeziteyle anlamlı ilişkisi devam etmektedir. Kadınlara göre erkeklerde obezite riski 2,52 kat $(\mathrm{OR}=2,52, \quad \% 95$ GA: 1,57-4,05); üniversite ve üstü öğrenimi olanlara göre lise düzeyinde öğrenimi olanlarda 2,61 kat (OR=2,61, \%95 GA: 1,67-4,09), ortaokul ve daha az öğrenime sahip olanlarda 4,09 kat (OR=4,09 \%95 GA: 2,68-6,24); kronik hastalığı olmayanlara göre kronik hastalığ olanlarda 1,89 kat $(\mathrm{OR}=1,89 \% 95$ GA: 1,302,76) fazladir $(p<0,05)$. Ailesinde obezite öyküsü olanlarda obezite riski 1,74 kat $(\mathrm{OR}=1,74$, \%95GA: 1,22-2,49) artmış bulunmuştur (Tablo 5). 
Tablo 5. Obezite İle Sosyodemografik Özellikler Ve Ailesel Obezite Arasındaki İlişkinin Çok Değişkenli Analizle İncelenmesi $(\mathbf{N}=657)$

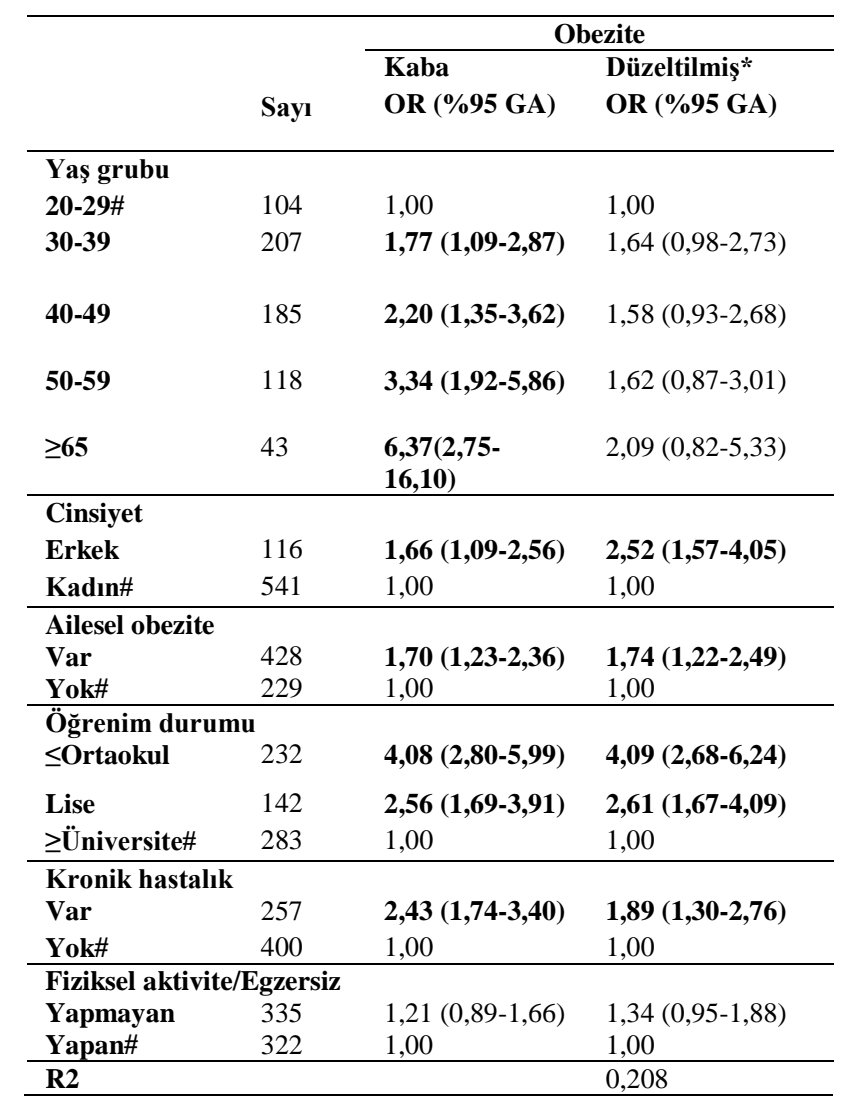

* Yaş, cinsiyet, öğrenim durumu, ailesel obezite varlı̆̆l, kronik hastalık varlığl, egzersiz yapma durumuna göre düzeltilmiş

\# Referans kategori

Birinci basamak sağlık hizmetleri, evrensel erişilebilirlik, ihtiyaç temelli kapsam1 gibi özellikleriyle obezitenin önlenmesi, kontrolü ve tedavisinin geliştirilmesi için önemli bir ortam sağlamaktadır. ${ }^{20} \quad$ Birinci basamakta SBODB'ye başvuran bireylerde yapılan bu araştırmada erkeklerde, evli olanlarda, kronik hastalığı olanlarda obezite sıklı̆ıının daha fazla olduğu bulunmuştur. Obezitenin yaş ile doğrusal olarak arttı̆ı, öğrenim düzeyi ile ters yönde bir ilişki olduğu saptanmıştır. Ailesinde obezite öyküsü olanlarda obezitenin daha sık görüldüğü belirlenmiştir.

Dünya Sağlık Örgütü, obezitenin yalnızca gelişmiş ülkelerde değil gelişmekte olan ülkelerde de yaygın olduğunu, gelişmekte olan ülkelerde 115 milyondan fazla insanın obeziteyle ilişkili sağlık sorunları yaşadığını belirtmektedir. ${ }^{1}$ Bu araştırmada SBODB'ye başvuranların \%58,4'ünün obez, \%31,7'sinin fazla kilolu olduğu belirlenmiş̧tir. Portekiz'de 2015-2016 yıllarında ülke çapında yapılan toplum tabanlı bir çalışmada obezite sıklı̆ $\% 22,3$ olarak bulunmuştur. ${ }^{21}$ Türkiye Beslenme ve Sağlık Araştırması'nda (TBSA 2017) 19 yaş ve üzeri toplumda obezite sıklığı \%32,2; TBSA 2010'da ise bu siklık $\% 30,3$; TURDEP II çalışmasında $\% 31,2$ olarak bulunmuştur. ${ }^{5,22} 2017$ y1lında yapılan Türkiye Bulaşıcı Olmayan Hastalıkların Prevalansı Hanehalkı Sağlık Araştırmasında (STEPS，2017) obezite skklı̆̆ ise \%28,8 olarak bulunmuştur. ${ }^{23}$ Çayır ve ark. beslenme ve diyet kliniğine başvuranlar bireyler ile yürüttükleri çalışmalarında obezite sıklı̆̆ını $\% 28$ olarak saptamıștır, başvuranların $\% 18$,2'sinin başvuru nedeni obezitedir. ${ }^{15}$ Batı Karadeniz Bölgesinde 18 yaş ve üzeri toplumda yapılan bir çalışmada obezite sıkllğı $\% 43,5$ olarak bulunmuştur. ${ }^{24}$ Aile hekimliğine başvuran 20 yaş ve üstü bireylerde obezite sıklı̆g $\% 59,6$ olarak saptanmıştır. ${ }^{25}$ Yukarıda obezite sıklı̆ğ incelenen çalışmalar bizim çalışmamızdan farklı olarak genel toplumda yapıldığı göz önünde bulundurulmalıdır. $\mathrm{Bu}$ araştırma SBODB'ye başvuran risk altındaki bir grupta yapıldığı için obezite sıklı̆ı̆ının topluma göre yüksek olması beklenen bir sonuçtur. Katılımcıların dörtte üçü kadınlardan oluşan birinci basamakta obezite danışma birimine başvuranlarda yapılan bir çalışmada obezite sıklığı bizim çalışmamızla benzer bulunmuştur. ${ }^{18} \mathrm{Bu}$ sonuçlar obeziteyle mücadele için birinci basamakta obezite danışmanlığının gerekliğini ve önemini ortaya koymaktadır.

$\mathrm{Bu}$ araştırmada ailesinde obezite öyküsü olanlarda obezitenin daha sik görüldüğü belirlenmiştir. Yapılan hem tek değişkenli analizde hem de regresyon analizinde ailesinde obezite öyküsü olanlarda obezite riskinin 1,7 kat arttığı belirlenmiştir. Obezite danışmanlığında çevresel faktörlerin sorgulanması gerekmektedir. ${ }^{26}$ Hastaya riskli davranış değişimi konusunda verilen önerilerde aile çevresi ve ortamını dikkate almak önemlidir. ${ }^{27}$ Ailede obezite öyküsü ve çocuklukta obezite, yetişkin obezitesi ile güçlü bir şekilde bağlantılıdır, bu ikisinin de hem genetik hem de davranışsal faktörlerden kaynaklanması olasıdır. ${ }^{10,16,26}$ Yapılan bir meta-analiz çalışmada ailesinde obezite 
öyküsü olanlarda obezite riskinin 2,2 kat arttığı saptanmıştır. ${ }^{16}$ İran'da çok merkezli büyük bir örnekle yapılan, tüm ailenin antropometrik özelliklerinin değerlendirildiği çalışmada ailesinde fazla kilo öyküsü olanlarda obezite 1,4 kat, obezite öyküsü olanlarda ise 1,5 kat arttığı gösterilmiştir. ${ }^{12}$ Yine İran'da yapılan kesitsel bir çalışmada ailede obezite öyküsü olan erkelerde obezite 2,5 kat fazla iken, kadınlarda 3,5 kat fazla bulunmuştur. ${ }^{11}$ Çayır ve ark. beslenme ve diyet kliniğine başvuranlarda yaptığ 1 çalışmada ailesinde obez kişi olduğunu belirtenlerde obezite sıklığının daha fazla olduğunu belirlemiştir. ${ }^{15}$ Türkiye'de farklı yaş gruplarında yapılan çalışmalarda ailede obezite öyküsü olanlarda obezitenin daha fazla görüldüğü saptanmıştır. ${ }^{28,29}$ Sakarya ve ark. tarafindan niteliksel ve niceliksel araştırma yöntemlerinin birlikte kullanılarak yapılan bir çalışmada, hareketsizlik ve sağlıksız beslenmenin çocukluk çağ 1 obezitesinin iki temel nedeni olduğu belirlenmiştir. $\mathrm{Bu}$ iki nedenin altında yatan nedenlerin ise çevreyle, toplumla ve aileyle ilgili etkenler olduğu belirtilmiştir. ${ }^{30}$

$\mathrm{Bu}$ araştırmada yalnız annenin ya da yalnız babanın obez olmasına göre hem annenin hem de babanın obez olmasinın bireylerin obez olmasinda anlamlı bir risk faktörü olduğu bulunmuştur. 1980-2003 yıllarında Avrupa, Asya, Kuzey ve Güney Amerika ülkelerinde yapılan, ailesel obezitenin incelendiği araştırmaların derlendiği bir meta-analiz çalışmada annelerde fazla kilolu olma siklığı \%22 ile $\% 43$, babalarda ise \%16 ile \%55 arasında olduğu belirlenmiştir. ${ }^{16}$ Ailede her iki ebeveynin fazla kilolu/obez olması bireydeki obezite riskini artırmakla birlikte annenin obezite öyküsü çocuk üzerinde daha etkindir. ${ }^{10,12}$ Annede obezite varlığ 1 bireyin obezite riskini $2,4 \mathrm{~kat}$, babada obezite varlı̆ 1 ise riski 2,1 kat artırmaktadır. ${ }^{16} \mathrm{Bu}$ sonuçlardan farklı olarak son yıllarda yapılan bir meta-analiz çalışmada ailesel obezite ile bireyin obezitesi arasında anlamlı ilişki saptanmamış, ailesel obezitenin bireysel obeziteye biyolojik ve sosyal etkilerinin düzeyini aydınlatmak için daha fazla araştırmaya ihtiyaç olduğu vurgulanmıştır. ${ }^{9}$
Obezite hastalarında gen paneli analizi son yıllarda tartışılan bir konudur. Genetik obezitenin teşhisi için yararlı olabileceği ve hastaların tedavisi üzerinde ciddi etkileri olabileceği öne sürülmektedir. ${ }^{31}$ Ailesinde obezite öyküsü olan obez bireylere danışmanlık sunumunda çevresel faktörler modifiye edilmeli, anne ve babanın katılımı sağlanarak aile bütüncül olarak desteklenmelidir. ${ }^{3,13,14}$

Genel olarak, erkekler daha yüksek kilolu olsalar da kadınlar daha yüksek obezite oranlarına sahiptir. ${ }^{1}$ Türkiye Kronik Hastalıklar ve Risk Faktörleri Sıklığı çalışmasında obezite sıklığ kadınlarda ise \%29 bulunmuştur. ${ }^{32}$ STEPS 2017 çalışmasında ise obezite sıklığı erkeklerde \%21,6; kadınlarda ise \%35,9 bulunmuştur. ${ }^{23}$ İzmir'de yapılan Balçova'nın Kalbi (BAK) kohort çalışmasında obezite sıklığ1 erkeklerde \%28,3, kadınlara \%29,6 bulunmuştur. $^{33}$ Obezite görülme sıklığ1 TBSA 2010'da erkeklerde \%20,5; kadınlarda $\% 41,0$; TURDEP II çalışmasında ise bu sıklık erkeklerde \%27,3; kadınlarda \%44,2 bulunmuştur. $^{5,22}$ Batı Karadeniz Bölgesinde 18 yaş ve üzeri toplumda yapılan bir çalışmada kadınlarda obezite sıklığı \%53,1, erkeklerde ise \%26,9 olarak bulunmuştur. ${ }^{24}$ Zileli ve ark. tarafından yapılan tüm katılımcıların kadın olduğu araştırmada grubunun \%62'sinin obez olduğu belirlenmiştir. ${ }^{34}$ Deniz ve ark. 20 yaş ve üzeri grupta kadınlarda obezite oranının daha fazla olduğu bulunmuştur. ${ }^{35}$ Portekiz'de yapilan toplum tabanlı çalışmada kadınlarda obezite $(\% 24,3)$ siklığ 1 erkeklerden $(\% 20,1)$ daha yüksektir. $^{21} \mathrm{Bu}$ çalışmamızda SBODB'ye başvuran erkeklerde obezite sıklığının kadınlara göre 2,5 kat daha fazla olduğu belirlenmiştir.

Bulaşıcı olmayan hastalıklar için en önemli risk faktörlerinden biri olan obezite 60'l1 yaşlara kadar yaşla birlikte artmaktadır. ${ }^{1,21} \mathrm{Bu}$ araştırmada katılımcıların yaşı arttıkça obezite sıklığının arttığ1 belirlenmiştir. Ancak yapılan regresyon analizinde bu anlamlılık ortadan kalkmıştır. Yapılan çalışmalarda bu araştırmada elde edilen bulguya paralel olarak katılımcıların 
yaşı arttıkça obezite sıklı̆̆ının arttı̆̆ bulunmuştur. ${ }^{11,15,24,25,34-36}$ Türkiye Kronik Hastalıklar ve Risk Faktörleri Sıklığı çalışmasında yaşla birlikte obezitenin arttığ 1 , erkeklerde en yüksek obezite sıklığ $45-54$ yaş grubunda iken kadınlarda en yüksek 5564 yaş grubunda olduğu görülmüştür. ${ }^{32}$

Vücut ağırlığı kaybını kolaylaştırmak için çevresel faktörlerin sorgulanması gerekebileceğinden, bir kilo verme stratejisi oluştururken hastanın eğitimini ve ortamını dikkate almak önemlidir. ${ }^{26}$ Gelişmiş ülkelerde yapılan çalışmalarda obezitenin eğitim düzeyi ile ilişkili olduğu gösterilmiștir. Eğitim düzeyi düşük olanlar da obezite daha sik görülmektedir. ${ }^{13,16,21} \mathrm{Bu}$ araştırmaya katılan bireylerin öğrenim düzeyi ile obezitenin ters ilişkili olduğu görülmüştür. Öğrenim düzeyi azaldıkça obezitenin arttığı belirlenmiştir. Lise düzeyinde öğrenimi olanlarda obezite 2,6 kat, ortaokul ve daha az öğrenime sahip olanlarda 4,1 kat fazladır. Çayır ve ark. çalışmalarının sonuçları bu çalışmanın bulgularıyla uyumlu olarak düşük eğitim düzeyi ile obezite arasında ilişki olduğunu göstermiştir. ${ }^{15}$ Aile hekimliğine başvuran bireyler ile yürütülen bir başka çalışmada ve bir ilçede yaşayan 20 yaş ve üzeri grupta yapılan diğer bir çalışmada da bu çalışmanın sonuçlarıyla uyumlu sonuçlar bulunmuştur. ${ }^{25,35} \mathrm{Bu}$ çalışmadan farklı olarak bir üniversite hastanesinin iç hastalıkları polikliniğine başvuran bireyler ile tamamlanan bir çalışmada öğrenim düzeyi ile obezite arasında ilişki saptanmamıştır. ${ }^{29}$ Obezitede psikososyal etmenlerin rolü önemlidir. Yüksek öğrenim düzeyine sahip olan bireylerin sosyal yaşamda daha aktif olması, bilinçli olarak sağlıklı yaşam alışkanlıkları edinmiş olması bu sonuçlarda etkili olabilir.
$\mathrm{Bu}$ araştırmada evli bireylerde evli olmayanlara göre obezite sıklığının daha yüksek olduğu belirlenmiştir. Türkiye'de erişkin yaş grubunda yapılan çalışmalarda bu bulguyla uyumlu olarak evli olan bireylerde obezitenin daha yüksek düzeyde olduğunu gösteren çalışmalar bulunmaktadır. ${ }^{25,35}$ Medeni durumun obeziteye etkisini bu çalışmanın sonuçlarından farklı bulan çalışmalar da mevcuttur. ${ }^{15,29}$ Çayır ve ark. tarafından beslenme ve diyet kliniğine başvuranlarda yaptığı çalışmada medeni durumunu dul olarak belirtenlerde obezite sıklığının daha yüksek olduğu belirlenmiştir. ${ }^{15}$ Diğer bir çalışmada ise medeni durum ile obezite arasında ilişki olmadığ1 saptanmıştır. ${ }^{29}$ Evlilik sonrası bireyler daha düzenli bir rutin benimseyebildiğinden, yaşam alışkanlıkları değişebilmektedir. Bu çalışmaya katılanların çoğunluğu kadın olduğu için gebelik ve menopoz vücut ağırlığı artışına zemin hazırlamış olabilir.

$\mathrm{Bu}$ araştırmada herhangi bir kronik hastalığı olan bireylerde obezitenin daha fazla görüldüğü saptanmıştır. Türkiye'de erişkin yaş grubunda yapılan çalışmalarda, bu araştırmadaki bulguyla uyumlu olarak, tanı almış herhangi bir kronik hastalığı olan bireylerde obezitenin daha yüksek olduğu gösterilmiştir. ${ }^{24,25}$ Obezite bazı kronik hastalıkların ortaya çıkışında bir risk faktörüdür ve hastalığın seyrini ağırlaştırabilmektedir. ${ }^{1,3}$ Kronik hastalığ1 olan obez bireylerin psikososyal ve motivasyon yönünden yardım ve desteğe ihtiyac1 olabilmektedir. ${ }^{8} \mathrm{Bu}$ nedenle birinci basamakta obezite için müdahaleler geliştirilirken bireye özgü yaklaşımlar geliştirilmelidir.

\section{SONUÇ VE ÖNERÍLER}

Sağlık açısından obeziteyi önlemek tedavi etmekten daha kolay ve daha etkilidir. Obezitenin önlenmesinde multidisipliner bir anlayışla koruyucu sağlık hizmetleri sunulan birinci basamak sağlık hizmetlerinin önemi büyüktür. $\mathrm{Bu}$ çalışmanın sonucunda birinci basamak sağlık hizmetlerinde bir SBODB'ye başvuran yetişkin bireylerin \%90'ının fazla kilolu veya obez olduğu, yaklaşık üçte ikisinin ailesinde obezite öyküsü olduğu belirlenmiştir. Evli olan bireylerde ve en az bir kronik hastalık tanısı olan bireylerde obezite sıklığının daha yüksek olduğu, obezitenin yaş ile arttığı, öğrenim düzeyinin 
artışı ile azaldığı saptanmıştır. Bu sonuçlar, ailesel obezite öyküsü olan bireylere yönelik sağlıklı beslenme ve yaşam tarzı alışkanlıkları konusunda birinci basamak sağl1k hizmetleri çalışmalarına yol gösterici olabileceğini göstermektedir. Diyetisyenlerin obezitenin önlenmesi ve sağlıklı yaşamın sürdürülmesindeki rolü büyüktür. Obez bireylerin diyet davranışlarını kendi başlarına değiştirmeleri oldukça güçtür. Bu nedenle bir diyetisyen tarafindan verilen davranıșsal destek obeziteyi azaltmada etkili olabilmektedir. Aile öyküsünde obezite bulunan bireylere, obez olmasa dahi beslenme tipi ve sağliklı beslenme konularında davranış değişimine yönelik danışmanlık yapılması önemlidir. Obeziteye zemin hazırlayan, ailede edinilen beslenme alışkanlıkları, yaşam tarzı davranışları gibi değiştirilebilir faktörlere yönelik önleme ve girişim çalışmalarının yapılması obezitenin önlenmesi ve kontrolünde önemli bilgiler verebilir.

\section{KAYNAKLAR}

1. World Health Organization. (2021). "Controlling The Global Obesity Epidemic”. Erişim adresi: http://www.who.int/nutrition/topics/obesity/en/ (Erișim tarihi: 28 Ocak 2021)

2. World Health Organization. (2021). "Obesity and Overweight”. Erişim adresi: http://www.who.int/en/news-room/fact-

sheets/detail/obesity-and-overweight (Erişim tarihi: 28 Ocak 2021).

3. Bhuyan, S.S, Chandak, A, Smith, P, Carlton, E.L Duncan, K. and Gentry, D. (2015). "Integration of Public Health and Primary Care: A Systematic Review of The Current Literature in Primary Care Physician Mediated Childhood Obesity Interventions". Obesity Research \& Clinical Practice, 9, 539-552.

4. T.C. Sağlık Bakanlığı Türkiye Halk Sağlığı Kurumu (2013). Türkiye Sağlıklı Beslenme ve Hareketli Hayat Programı (2014-2017). Ankara: Sağlık Bakanlığı Yayınları.

5. T.C. Sağlık Bakanlığ Türkiye Halk Sağlığı Kurumu (2019). Türkiye Beslenme ve Sağlık Araștırmas (TBSA). Ankara: Sağlık Bakanlığı Yayını.

6. World Health Organization. (2013). Global Action Plan For The Prevention And Control Of Noncommunicable Diseases 2013-2020. Geneva, Switzerland: WHO Press.

7. Imanaka, M, Ando, M, Kitamura, T. and Kawamura, T (2016). "Impact of Registered Dietitian Expertise in Health Guidance for Weight Loss". PLoS ONE, 11 (3), e0151456.

8. Leung, A.W.Y, Chan, R.S.M, Sea, M.M.M. and Woo, J (2017). "An Overview of Factors Associated with Adherence to Lifestyle Modification Programs for Weight Management in Adults". Int. J. Environ. Res. Public Health, 14, 922.

9. Wang, Y, Min, J, Khuri, J. and Li, M. (2017). "A Systematic Examination of The Association Between Parental and Child Obesity Across Countries". Adv Nutr, 17 (8), 436-448.

10. Gray, L.A, Alava, M.H, Kelly, M.P. and Campbell, M.J. (2018). "Family Lifestyle Dynamics and Childhood Obesity: Evidence From The Millennium Cohort Study". BMC Public Health, 18, 500.
11. Bahreynian, M, Qorbani, M, Khaniabadi, B.M, Motlagh, M.E, Safari, O, Asayesh, H. and Kelishadi, R. (2017). "Association between Obesity and Parental Weight Status in Children and Adolescents". J Clin Res Pediatr Endocrinol, 9 (2), 111-117.

12. Ejtahed, H.S, Heshmat, R, Motlagh, M.E, HasaniRanjbar, S, Ziaodini, H, Taheri, M, Ahadi, Z, Aminaee, T, Shafiee, G, Goodarzi, A, Qorbani, M. and Kelishadi, R. (2018). "Association of Parental Obesity with Cardiometabolic Risk Factors in Their Children: The CASPIAN-V Study”. PLoS ONE, 13 (4), e0193978.

13. Brown, C.L. and Perrin, E.M. (2018). "Obesity Prevention and Treatment in Primary Care". Academic Pediatrics, 18 (7), 736-745.

14. Lowe, M.R, Shank, L.M, Mikorski, R. and Butryn, M.L. (2015). "Personal History of Dieting and Family History of Obesity Are Unrelated: Implications for Understanding Weight Gain Proneness". Eat Behav, 17, 144-148.

15. Cayır, A, Atak, N. ve Köse, SK. (2011), "Beslenme ve Diyet Kliniğine Başvuranlarda Obezite Durumu ve Etkili Faktörlerin Belirlenmesi". Ankara Üniversitesi T1p Fakültesi Mecmuası, 64 (1), 13-19.

16. Kanciruk, M, Andrews, JW and Donnon, T. (2014) "Family History of Obesity and Risk of Childhood Overweight and Obesity: A Meta-Analysis". International Journal of Psychological and Behavioral Sciences, 8 (5), 261-273.

17. Forhan, M, Risdon, C. and Solomon, P. (2013). "Contributors to Patient Engagement in Primary Health Care: Perceptions of Patients With Obesity". Prim Health Care Res Dev, 14 (4), 367-372.

18. Kahraman Görgel, H, Orbahçı, B.M, Alpay, S, Yılmaz, T.S. ve Kocasarı, B. (2019). "Birinci Basamakta Obezite Danışma Birimine Başvuran Obez ve Fazla Kilolu 18 Yaş Üstü Kişilerin İzlemlerinin Değerlendirilmesi”. ESTÜDAM Halk Sağlığı Dergisi, 4 (3). 314-21.

19. World Health Organization. (2021). "Body mass index BMI". Erişim adresi: https://www.euro.who.int/en/health-topics/diseaseprevention/nutrition/a-healthy-lifestyle/body-massindex-bmi (Erişim tarihi: 28 Temmuz 2021).

20. Marques, E.S. (2018). "Effective Strategies for Prevention, Control, and Treatment of Obesity in Primary Health Care Setting for Adolescents, Adults, and Elderly People A Protocol for Systematic Review and Meta-analysis”. Medicine, 97, 22(e10925). 
21. Oliveira, A, Araújo, J, Severo, M, Correia, D, Ramos, E Torres, D, Lopes, C. and The IAN-AF Consortium. (2018). "Prevalence of General and Abdominal Obesity in Portugal: Comprehensive Results From The National Food, Nutrition and Physical Activity Survey 20152016”. BMC Public Health, 18 (1), 614.

22. Satman, I, Omer, B, Tutuncu, Y, Kalaca, S, Gedik, S, Dinccag, N, Karsidag, K, Genc, S, Telci, A, Canbaz, B, Turker, F, Yilmaz, T, Cakir, B, Tuomilehto, J. and TURDEP-II Study Group. (2013). "Twelve-Year Trends in The Prevalence and Risk Factors of Diabetes and Prediabetes in Turkish Adults". Eur J Epidemiol, 28 (2), 169-180.

23. Üner S, Balcilar M. Ve Ergüder T. (2018). Türkiye Hanehalkı Sağlık Araştırması: Bulaşıcı Olmayan Hastalıkların Risk Faktörleri Prevalansı 2017 (STEPS) Ankara: Dünya Sağlık Örgütü Türkiye Ofisi.

24. Aydın, Y, Celbek, G, Kutlucan, A, Önder, E, Güngör, A Alemdar, R, Coşkun, H. ve Özhan, H. (2012). "Bat Karadeniz Bölgesinde Obezite Prevelansı: Melen Çalıșması". Turkish Journal of Endocrinology and Metabolism, 16, 52-57.

25. Işık, E, Kanbay, Y, Aslan, Ö, Işık, K. ve Çınar, S. (2013). "Aile Hekimliği Birimine Başvuran Bireylerde Obezite Sıklığı ve İlişskili Etmenler: Artvin Örneği”. F.N. Hemşirelik Dergisi, 21 (2), 107-115.

26. Fruh, S.M. (2017). "Obesity: Risk Factors, Complications, and Strategies for Sustainable Long-term Weight Management". Journal of the American Association of Nurse Practitioners, 29, S3-S14.

27. Schutz, D.D, Busetto, L, Dicker, D, Farpour-Lambert, N, Pryke, R, Toplak, H, Widmer, D, Yumuk, V. and Schutz, Y. (2019). "European Practical and Patient-Centred Guidelines for Adult Obesity Management in Primary Care". Obes Facts, 12 (1), 40-66.

28. Aktaş, D, Öztürk, F.N. ve Kapan, Y. (2015) "Adölesanlarda Obezite Sıklığı ve Etkileyen Risk Faktörleri, Beslenme Alışkanlıklarının Belirlenmesi”. TAF Prev Med Bull, 14 (5), 406-412.

29. Erkol, A. ve Khorshid L. (2004). "Obezite; Predispozan Faktörler ve Sosyal Boyutun Değerlendirilmesi”. SSK Tepecik Hast Derg, 14 (2), 101-107.

30. Sakarya, S, Kanlı, S, İkiışık, H, Marak, I, Taşdemir, M, Topçu, İ. ve Çalı, Ş. (2017). "Aileler, Öğretmenler ve Aile Hekimlerinin Gözüyle Cocukluk Cağı Obezitesi: Bir Karma Metod Çalışması”. The Journal of Turkish Family Physician, 8 (2), 27-39.

31. Kleinendorst, L, Massink, M.P.G, Cooiman, M.I, Svas, M, van der Baan-Slootweg, O.H, Roelants, R.J, Janssen, I.J.M, Meijers-Heijboer, H.J, Knoers, N.V.A.M, van Amstel, H.K.P, van Rossum, E.F.C, van den Akker, E.L.T, van Haaften, G, van der Zwaag, B. and van Haelst, M.M. (2018). "Genetic Obesity: Next-Generation Sequencing Results of 1230 Patients with Obesity". J Med Genet, 55 (9), 578-586.

32. Ünal, B. ve Ergör, G. (2013). Türkiye Kronik Hastalıklar ve Risk Faktörleri Sıklığı Çalışması. Ankara: Sağlık Bakanlığı Yayınları. Yayın No: 909.

33. Ergör, G, Soysal, A, Sözmen, K, Ünal, B, Uçku, R, Kılıç, B, Günay, T, Ergör, A, Demiral, Y, Saatlı, G, Meseri, R, Baydur H, Şimşek H, Budak, R, Arık, H. and Karakuş, N. (2011). "Balcova Heart Study: Rationale and Methodology of The Turkish Cohort". Int J Public Health, 57, 535-542.
34. Zileli, R, Simsek, O, Ozkamçı, H. ve Diker, G. (2016). "Bilecik İlinde Yaşayan Kadınlarda Spora Katılım, Obezite Prevalansı ve Risk Faktörleri”. Marmara Üniversitesi Spor Bilimleri Dergisi, 1 (1), 85-98.

35. Deniz, S. ve Oğuzöncül, A.F. (2020). "Bir İlçede Yaşayan Erişkinlerde Obezite Sıklığ 1 ve İlişkili Faktörler”. ESTÜDAM Halk Sağlığı Dergisi, 5 (1), 53 61

36. Assk, Z ve Cakmak, T. (2016). "Aile Hekimliğ Polikliniğine Başvuran Hastalarda Obezite ve Metabolik Sendrom Değerlendirmesi". The Journal of Turkish Family Physician, 7 (4), 94-102. 